\title{
TEMUR GIRING (Curcuma heyneana Val.): SEBUAH TINJAUAN MORFOLOGI, FITOKIMIA, DAN FARMAKOLOGI
}

\author{
Muhamad Jalil \\ Mahasiswa Program Studi Doktor Biologi Universitas Gadjah Mada \\ muhamadjalil@mail.ugm.ac.id
}

\begin{abstract}
ABSTRAK
Temu giring sebagai tanaman komoditas obat memberi kontribusi masih dibawah 5\%, sedangkan produksi kunyit lebih memberikan kontribusi produksi lebih besar dengan prosentase sebesar $18,82 \%$. Tujuan dari tinjauan ini adalah untuk menyajikan informasi yang komprehensif mengenai morfologi, konstituen kimia, penelitian biologi tentang farmakologi sebagai bukti ilmiah khasiat temu giring untuk pengembangan lebih lanjut dalam pengobatan tradisional. Penelitian ini merupakan penelitian kepustakaan. Data penelitian berupa jurnal dan buku tentang temu giring dan tanaman obat tradisional (jamu) serta dilengkapi dengan foto. Teknik analisis data menggunakan metode content analysis dengan cara membuat inferensi yang replicabel dan dengan data yang valid, dengan memperhatikan konteksnya. Morgologi temu giring menunjukkan warna rimpang berwarna kuning cerah. Rimpang temu giring memiliki aktivitas antioksidan, antivirus, antiaging, dan antimikroba. Senyawa aktif yang umumnya bertanggungjawab terhadap aktivitas farmakologi adalah golongan heyneanone, fenolik, saponin, flavonoid, dan minyak atsiri.
\end{abstract}

Kata Kunci: Farmakologi, Fitokimia, Morfologi, Temu Giring

\section{ABSTACT}

Teтu giring as a medicinal commodity contributes below 5\%, while turmeric production contributes more to production with a percentage of $18.82 \%$. The purpose of this review was to present comprehensive information on morphology, chemical constituents, biological research on pharmacology as scientific evidence of the efficacy of sleigh gatherings for further development in traditional medicine. This research is library research. The research data was in the form of journals and books about tiring giring and traditional medicinal plants (herbs) and equipped with photographs. The data analysis technique uses the content analysis method by making replicabel inferences and with valid data, taking into account the context. The morphology of the temu giring shows the color of the bright yellow rhizome. Rhizome temu giring has antioxidant, antiviral, antiaging and antimicrobial activity. The active compounds that are generally responsible for pharmacological activity are heyneanone, phenolic, saponine, flavonoids, and essential oils. 
Keywords: Pharmacology, Phytochemistry, Morphology, Temu Giring

\section{PENDAHULUAN}

Marga Curcuma memiliki anggota sebanyak 70 spesies (Hendrian and Hadiah, 1999, p. 21). Salah satu yang paling potensial untuk pengobatan dan kosmetika adalah temu giring. Temu giring masuk kedalam anggota marga Curcuma (Backer and Van Den Brink, 1968). Rimpang ini dikelompokkan spesies indigineous asli Indonesia (Bos et al., 2007). Nama dagang temu giring adalah temu giring (Syamsuhidayat and Hutapea, 1991, p. 190). Temu giring merupakan bagian komoditi tanaman obat yang ditetapkan melalui Keputusan Menteri Pertanian No 511/Kpts/PD.310/2006 tahun 2006 (Salim et al., 2017). Temu giring juga masuk daftar tanaman obat tradisional yang dipergunakan dalam buku "Pemanfaatan Tanaman Obat Departemen Kesehatan RI Edisi III Tahun 1983" (Tukiman, 2004) .

Temu giring sebagai tanaman komoditas obat memberi kontribusi masih dibawah 5\%, kalah jauh dengan rimpang kunyit yang memberikan kontribusi produksi lebih besar dengan prosentase sebesar 18,82\% (Salim et al., 2017, p. 2). Hasil observasi di Pasar Imogiri Bantul pada tanggal 17 Juli 2019, harga temu giring di Pasaran di jual dengan harga 4.000/rupiah. Banyak faktor yang menyebabkan rimpang temu giring kurang diminati oleh pasar. Hal ini sangat berkaitan erat dengan temu giring sebagai bahan baku pembuatan jamu, yaitu: (1) ketidakjelasan informasi, termasuk kandungan, efek samping, dan dosis; (2) pengetahuan masyarakat pengguna terhadap jamu; dan (3) loyalitas pengguna terhadap jamu, sebagian besar pengguna masih menempatkan jamu sebagai alternatif kepada obat farmasi (Salim et al., 2017).

Temu giring (Curcuma heyneana Val \& V. Zijp termasuk keluarga Zingiberaceae (Dzulkarnain et al., 1995, p. 24). Nama daerah temu giring adalah temureng dan temupala (Santoso, 1998, p. 85). Penduduk Bali menyebut temu giring dengan sebutan temu poh (Nuraeni and Yunilawati, 2012). Habitus semak, semusim, tegak, tinggi dapat mencapai 1 meter (Syamsuhidayat and Hutapea, 1991, p. 190). Ketinggian tempat $200 \mathrm{~m}-750 \mathrm{~m}$ di atas permukaan laut. Curah hujan tahunan 1000-3.500 mm/tahun. Bulan basah di atas $100 \mathrm{~mm} / \mathrm{bulan}$ (7 bulan 
- 9 bulan). Bulan kering di bawah $60 \mathrm{~mm} /$ bulan (3 bulan -5 bulan). Suhu udara $19^{\circ} \mathrm{C}-30^{\circ} \mathrm{C}$. Kelembaban yang dibutuhkan temu giring sedang dan penyinaran tinggi (Santoso, 1998, p. 85).

Temu giring dapat tumbuh pada tanah lotosol merah cokelat, tekstur lempung berkilat dan lempung merah (Santoso, 1998, p. 85). Drainase harus baik, kedalaman air tanah di atas $25 \mathrm{~cm}$ dari permukaan tanah. Kedalaman perakaran 10 cm-25 cm dari permukaan tanah. Kemasaman atau pH antara 6-7. Temu giring dapat tumbuh pada kesuburan sedang sampai tinggi. Temu giring ditemukan tumbuh liar di hutan-hutan kecil atau peladangan dekat rumah penduduk, terutama dikawasan Jawa Timur (Muhlisah, 1999, p. 54).

Khasiat temu giring berkhasiat sebagai obat cacing pada anak-anak dan dipakai untuk bedak (kosmetika) (Syamsuhidayat and Hutapea, 1991, p. 190). Khasiat lain temu giring dapat memperhalus kulit, melangsingkan tubuh, obat sakit perut, dan melancarkan pencernaan (Jane Beers, 2001, p. 88; Salim et al., 2017, p. 24). Temu giring dimanfaatkan secara tradisional oleh masyarakat Madura untuk membuat pilis agar peredaran darah lancar pada bagian kepala. Pilis ditempelkan dikening ibu yang sedang melakukan proses persalinan. Pilis terbuat dari kencur (konceh), kunir (konyeh/temu koneng), temu giring (luthi), bengle, krangehan, jeruk purut, cengkih, daun kemukus, dan madu (Mudjijono et al., 2014). Sementara itu di Sumenep temu giring merupakan bahan baku untuk membuat Lulur Scrap bersama temulawak, kulit kerang, beras, dan bahan dupa. Lulur scrap dipercaya masyarakat Sumenep dapat menghaluskan dan membersihkan kulit (Mudjijono et al., 2014).

Pedagang empon-empon di Pasar Imogiri di Bantul mengungkapkan jika temu giring merupakan bahan baku pembuatan uyup-uyup. Temu giring di Bantul dimanfaatkan sebagai obat Cekok. Temu giring merupakan contoh tanaman obat yang mudah di tanam dalam segala kondisi. Oleh karena itu temu giring masuk dalam daftar dari 26 tanaman obat yang direkomendasikan di tanam di wilayah perkotaan sebagai apotik hidup (Dwisatyadini, 2017). Temu giring bermanfaat sebagai obat cacingan (Salim et al., 2017, p. 24).

Informasi terkait dengan banyaknya kegunaan temu giring secara empiris dan hasil penelitian yang telah dilakukan terkait khasiat temu giring, maka penting 
digali informasi lebih mendalam terkait dengan morfologi, senyawa fitokimia, dan aktivitas farmakologinya, sehingga dapat dijadikan bukti ilmiah dalam pengembangan dan penelitian lebih lanjut untuk peningkatan kemanfaatan dalam aspek pengobatan.

\section{METODE}

Penelitian ini merupakan penelitian kepustakaan atau library research. Penelitian ini dilakukan melalui mengumpulkan data atau karya tulis ilmiah yang bertujuan dengan obyek penelitian atau pengumpulan data yang bersifat kepustakaan, atau telaah yang dilaksanakan untuk memecahkan suatu masalah yang pada dasarnya tertumpu pada penelaahan kritis dan mendalam terhadap bahan-bahan pustaka yang relevan. Penelitian ini dilakukan di Perpustakaan Biologi UGM Yogyakarta Gedung B Lantai 3. Sedangkan waktu untuk melakukan penelitian ini adalah pada tanggal Juli-Agustus 2019. Pendekatan yang digunakan dalam penelitian ini, menurut peneliti, adalah pendekatan historis. Pendekatan historis yang digunakan di sini adalah dimaksudkan untuk meneliti beberapa penelitian temu giring yang pernah dilakukan oleh berbagai institusi di dalam dan luar negeri.

Sumber primer adalah hasil-hasil penelitian jurnal temu giring. Sumber data sekunder berupa foto dan buku terkait tanaman obat dan jamu. Teknik pengumpulan data yang digunakan dalam penelitian ini adalah pengumpulan data literer yaitu dengan mengumpulkan bahan-bahan pustaka yang berkesinambungan (koheren) dengan objek pembahasan yang diteliti. Langkah-langkah teknik literer adalah: (1) editing, yaitu pemeriksaan kembali dari data-data yang diperoleh terutama dari segi kelengkapan, kejelasan makna dan koherensi makna antara yang satu dengan yang lain; (2) Organizing yakni menyusun data-data yang diperoleh dengan kerangka yang sudah ditentukan; dan (3) Penemuan hasil penelitian, yakni melakukan analisis lanjutan terhadap hasil penyusunan data dengan menggunakan kaidah-kaidah, teori dan metode yang telah ditentukan sehingga diperoleh kesimpulan (inferensi) tertentu yang merupakan hasil jawaban dari rumusan masalah.

Teknik analisis data menggunakan metode analisis isi (content analysis). Teknik ini dilakukan untuk membuat kesimpulan-kesimpulan (inferensi) yang 
dapat ditiru (replicabel) dan dengan data yang valid, dengan memperhatikan konteksnya. Metode ini dimaksudkan untuk menganalisis seluruh pembahasan mengenai morfologi, fitokimia, dan farmakologi secara lebih mendalam. Penulis memulainya dari tahapan merumuskan masalah, membuat kerangka berpikir, menentukan metode operasionalisasi konsep, menentukan metode pengumpulan data, mengumpulkan metode analisis data yang kemudian sampai pada tahap interpretasi makna.

\section{HASIL DAN PEMBAHASAN}

\section{A. Deskripsi Morfologi Temu Giring}

Batang: semu, tegak, bulat, membentuk rimpang, hijau kekuningan (Syamsuhidayat and Hutapea, 1991, p. 188).

Daun: tunggal, lanset memanjang, helai daun tiga sampai delapan, ujung dan pangkal runcing, tepi rata, panjang 20-40 cm, lebar 8-12,5 cm, pertulangan menyirip, hijau pucat.

Bunga temu giring muncul dari bagian samping batang semu. Pinggiran mahkota bunga berwarna merah. Bunga ini mempunyai daun-daun pelindung (Bractea) yang berujung lancip. Musim bunga berlangsung dari bulan Agustus sampai bulan Mei tahun berikutnya, namun paling banyak ditemui pada bulan September sampai Desember (Muhlisah, 1999, p. 53).

Rimpag temu giring merupakan umbi batang yang tumbuh menyebar di sebelah kiri dan kanan batang secara memanjang sehingga terlihat kurus atau membengkok ke bawah. Rimpang temu giring tumbuh mengarah ke bawah dengan percabangan berbentuk persegi. Daging rimpang berwarna kuning cerah, berbau aromatis khas temu giring (Gambar 1). Rimpang bagian samping umumnya memiliki rasa lebih pahit (Muhlisah, 1999, p. 53). 

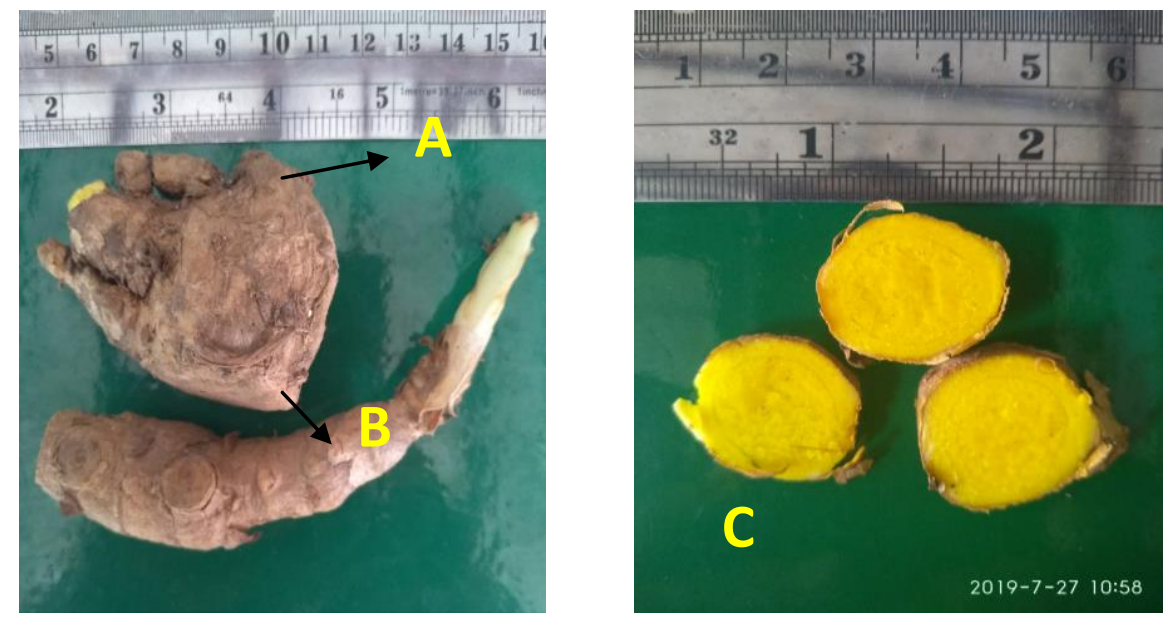

Gambar 1. Temu giring: (A) Empu temu giring; (B) Entik temu giring; dan (C) Irisan temu giring yang berwarna Kuning cerah

\section{B. Tinjaun Fitokimia}

\section{Rimpang}

Temu giring mengandung minyak atsiri sehinga dapat digunakan sebagai bumbu memasak (Syamsuhidayat and Hutapea, 1991, p. 190). Minyak Atsiri atau disebut juga dengan essential oils, etherial oils, atau volatile oils adalah salah satu komoditi yang memiliki potensi besar di Indonesia (Kemendag, 2014). Minyak Atsiri adalah ekstrak alami dari jenis tumbuhan tertentu, baik berasal dari daun, bunga, kayu, biji-bijian bahkan putik bunga.

Minyak Atsiri digunakan sebagai bahan baku minyak wangi, komestik dan obat-obatan. Minyak Atsiri juga digunakan sebagai kandungan dalam bumbu maupun pewangi (flavour and fragrance ingredients). Industri komestik dan minyak wangi menggunakan Minyak Atsiri sebagai bahan pembuatan sabun, pasta gigi, shampoo, lotion dan parfum (Kemendag, 2014). Industri makanan menggunakan Minyak Atsiri sebagai penyedap atau penambah cita rasa. Industri farmasi menggunakannya sebagai obat anti nyeri, anti infeksi, pembunuh bakteri. Fungsi Minyak Atsiri sebagai wewangian juga digunakan untuk menutupi bau tak sedap bahan-bahan lain seperti obat pembasmi serangga yang diperlukan oleh industri bahan pengawet dan bahan insektisida.

Penelitian melaporkan bahwa temu giring mengandung 8 minyak atsiri yang komponennya berupa: gamma-terpinen, $\beta$-terpinen, terpinolen, $\delta$-elemen, $\alpha$ - 
kopaen, guiazulen, karvon, dan 2-undekanon (Alulyant et al., 1996). Stuktur minyak atsiri dapat dilihat pada Tabel 1.

Tabel 1 Minyak Atsiri pada Temu Giring

\begin{tabular}{|c|c|c|c|}
\hline No & $\begin{array}{l}\text { Nama minyak } \\
\text { atsiri }\end{array}$ & Struktur Kimia & Sumber \\
\hline 1 & Gamma-terpinen & & $\begin{array}{l}\text { https://de.wikipedia.org/wiki/ } \\
\% \text { CE\%93- } \\
\text { Terpinen\#/media/Datei:Gam } \\
\text { ma_Terpinene.svg }\end{array}$ \\
\hline
\end{tabular}

2 Beta-terpinen<smiles>C=C1CC=C(C(C)C)CC1</smiles>

http://www.chemspider.com/ Chemical-

Structure.60205.html

3 Terpinolen<smiles>CC(C)C(C)c1ccc(O)cc1</smiles>
http://www.essentialoil.in/terp inolene.html

$4 \quad \delta$-elemen<smiles>CC(C)C1=CC2CC3CC(CC3C)C2C1</smiles>

(Alulyant et al., 1996)

$7 \quad \alpha$-kopaen

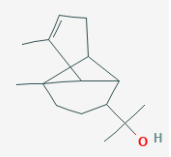

https://pubchem.ncbi.nlm.nih. gov/compound/alpha-Copaen11-ol\#section=2D-Structure

8 guiazulen

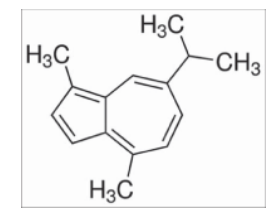

https://www.researchgate.net/ figure/Chemical-structure-ofguaiazulene_fig1_271232441

7 Karvon

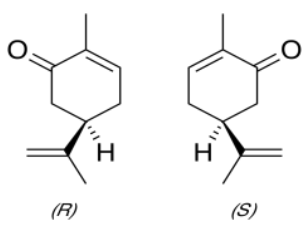

https://sl.wikipedia.org/wiki/ Karvon

8 2-undekanon

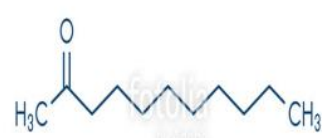

https://t4.ftcdn.net/jpg/01/93/5 3/91/500_F_193539132_x3x VF5F0EdI6ls6Vnv9haJqREm 7nAxfy.jpg 
Komponen kimia minyak atsiri temugiring dari hasil distilasi uap dan air adalah acetophenone sebanyak 18,93\%, camphor sebanyak $17,89 \%$, camphene sebanyak 8,39\%, dan sisanya berupa 1,8-cineole, $\beta$-elemene, aguaiene, curzerene, curzerenone, dan germacrone (Nuraeni and Yunilawati, 2012). Senyawa yang berhasil diisolasi Di antara senyawa yang diisolasi, heyneanone $\mathrm{A}$, heyneanone $\mathrm{C}$, 4,10-epizedoarondiol, procurcumenol, aerugidiol, zerumin A, dan $-15,16$ bisnorlabda-8, dan 11 -dien-13-one (Saifudin et al., 2013).

Temu giring mengandung senyawa kimia berupa fenolik (Yustin and Wijayanti, 2018). Senyawa fenolik adalah senyawa yang memiliki satu atau lebih gugus hidroksil $(\mathrm{OH})$ yang mengikat cincin aromatis fenol. Fenol adalah cincin siklis rantai 6 yang bersifat basa karena memiliki gugus $\mathrm{OH}$ (bersifat basa) oki disebut juga bensena (Anonim, 2014). Senyawa fenolik berperan dalam memberikan aroma yang khas pada produk makanan dan minuman, sebagai zat pewarna makanan dan minuman, dan sebagai antioksidan. Pada industri farmasi dan kesehatan, senyawa ini banyak digunakan sebagai antioksidan, antimikroba, antikanker dan lain-lain, contohnya obat antikanker, antimalaria dan obat demam. Selain itu, senyawa ini juga banyak digunakan sebagai insektisida dan fungisida. Selain itu, senyawa fenolik sangat penting untuk pertumbuhan dan reproduksi tanaman, di mana diproduksi sebagai respon untuk mempertahankan tanaman dari serangan terhadap patogen.

Temu giring juga mengandung senyawa flavonoid (Yustin and Wijayanti, 2018). Flavonoid adalah kelompok senyawa bioaktif yang banyak ditemukan pada bahan makanan yang berasal dari tumbuhan. Flavonoid serupa dengan antioksidan, yang memiliki beragam manfaat untuk tubuh Anda, seperti dapat memperbaiki sel yang rusak akibat radikal bebas. Suplemen flavonoid juga diduga bisa mengurangi risiko kanker, hipertensi, dan diabetes (Adrian, 2017).

Rimpang temu giring mengandung senyawa kurkumin yang dapat memberi warna kuning (Santoso, 1998, p. 86). Rimpang temu giring apabila dibelah akan terlihat warna kuning yang cerah (Muhlisah, 1999). Disamping itu rimpan mengandung senyawa saponin (Syamsuhidayat and Hutapea, 1991, p. 190).

Rimpang temu giring mengandung minyak atsiri 0,8-3\%, amilum, damar, lemak, tanin dan zat pahit, zat warna kuning, saponin, dan flavonoid (Yustin and 
Wijayanti, 2018). Temu giring atau kuning gajah adalah rimpang yang dimanfaatkan sebagai obat cacing karena mengandung piperazin sitrat yang diketahui dapat menangkal serangan cacing gelang (Ascaris) (Rahmawati, 2019).

Berikutnya temu giring mengandung senyawa saponin. Senyawa saponin adalah jenis senyawa kimia yang berlimpah dalam berbagai spesies tumbuhan. Senyawa ini merupakan glikosida amfipatik yang dapat mengeluarkan busa jika dikocok dengan kencang di dalam larutan. Busanya bersifat stabil dan tidak mudah hilang. Dalam literatur lain, Saponin diartikan sebagai senyawa glikosida steroid atau triterpen ditemukan dalam berbagai tanaman (Yanuartono et al., 2017).

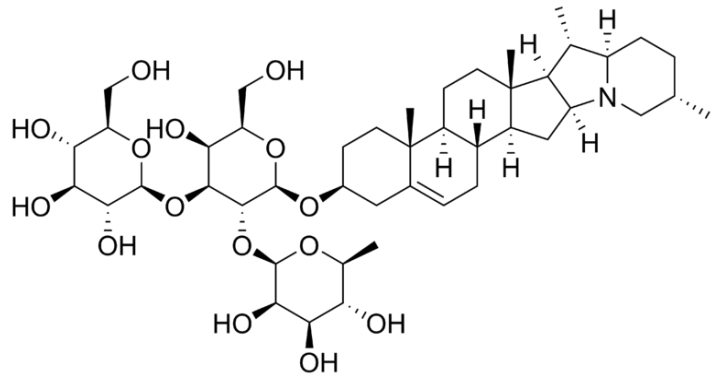

Gambar 2. Struktur Saponin

(https://id.wikipedia.org/wiki/Berkas:Solanine_chemical_structure.png)

\section{Tinjauan Farmakologis}

1) Temu giring sebagai antioksidan

Antioksidan merupakan molekul yang mampu memperlambat atau mencegah proses oksidasi molekul lain. Oksidasi adalah reaksi kimia yang dapat menghasilkan radikal bebas, sehingga memicu reaksi berantai yang dapat merusak sel. Berdasarkan hasil GC-MS senyawa yang diduga berperan aktif sebagai tabir surya adalah senyawa puncak 27 dengan konsentrasi 1,79\% yang memiliki indeks kemiripan dengan senyawa 1,4-naphthalenedione, 2hydroxy-3-2(2 methyl-1propenyl) (Maulida, 2016).

Temuan histopatologi hati dalam penelitian adalah kongesti sinusoid, nekrosis perivenural, perubahan inti sel dan perubahan lemak pada kelompok perlakuan tanpa kehilangan arsitektur tubular pada semua kelompok (Hapsari, 2015). Berdasarkan analisa hasil penelitian yang telah dilakukan dapat diambil 
kesimpulan bahwa pemberian infus rimpang temu giring pada dosis $10 \%, 20 \%$, dan $40 \%$ dapat menurunkan berat badan mencit jika dibandingkan dengan kelompok kontrol (hanya diberi air suling) (Setiowati, 2014).

2) Temu giring sebagai antivirus

Tanaman temu giring dapat dimanfaatkan sebagai obat antivirus. salah satu penggolongan obat yang secara spesifik digunakan untuk mengobati infeksi virus. Temu giring oleh Lolita (2014), dibuat Jamu Viranur yang mampu menurunkan titer virus menjadi $2^{0}$. Dengan demikian temu giring memiliki kemampuan antivirus.

3) Temu giring sebagai antiaging

Hasi penelitian yang menunjukkan temu giring memiliki aktivitas antiaging (pencegah penuaan pada wajah. Hal ini tidak salah beberapa temu giring digunakan sebagai bahan baku pembuatan bedak. Penuaan bisa disebabkan karena faktor usia dan faktor lingkungan yang mendominasi munculnya penuaan wajah. Hasil penelitian menunjukkan bahwa $C$. heyneana mengandung senyawa antioksidan dan memiliki aktivitas anti-penuaan yang kuat, menunjukkan bahwa itu dapat digunakan sebagai kandidat obat anti-penuaan atau sebagai sebuah phyto-cosmeceutical (Kusumawati et al., 2018).

Temugiring mengandung minyak atsiri, amilum, damar, lemak, tannin, saponin, dan favlonoida sehingga dapat di manfaatkan sebagai obat kecantikan yang baik untuk kulit sebagai bahan lulur ataupun campuran bedak untuk menghaluskan kulit (Arifah et al., 2011). Proses pembuatannya cukup mudah dengan langkah pertama mencuci temu giring sampai bersih, kemudian diiris tipis-tipis agak menyerong dengan ketebalan kira-kira $0,3 \mathrm{~cm}$. Temu giring yang sudah diiris kemudian ditata sejajar di atas loyang kue kering dan selanjutnya dikeringkan dengan oven sampai kering. Pengeringan $1 \mathrm{~kg}$ temu giring basah dapat menghasilkan kira-kira $1 / 4 \mathrm{~kg}$ temu giring kering. Temu giring kering digiling sampai halus bersamaan dengan ekstrak bunga kemudian ditambahkan tepung kanji sebagai bahan tambahan. Bahan tersebut kemudian di saring hingga menghasilkan bedak yang benar-benar halus

4) Temu giring sebagai anti-bakteri 
Sari rimpang temu giring terfermentasi menunjukkan aktivitas antioksidan dengan nilai IC50 sebesar 3,49 ppm, sehingga dapat disimpulkan bahwa sari rimpang temu giring terfermentasi memiliki aktivitas antioksidan yang tergolong sangat kuat (Yustin and Wijayanti, 2018).

Temu giring dapat dibuat salep sebagai antibakteri. Salep adalah sediaan setengah padat yang mudah dioleskan dan digunakan sebagai obat luar, bahan aktif akan larut atau terdispersi secara homogen dalam basis salep yang cocok (Lestari et al., 2017). Salep yang terbuat dari temu giring memiliki ciri-ciri warna krem gelap, bau temu giring masih kuat, rasa dingin lembut, homogen, daya sebar 61,79 mm, daya lekat 01,60 detik, pH 6, dan viskositas $39.000 \mathrm{cPa}$ 's (Lestari et al., 2017).

\section{SIMPULAN}

Temu giring merupakan anggota Zingiberaceae yang warna rimpang berwarna kuning cerah. Temu giring memiliki berbagai macam aktivitas antioksidan, antivirus, antiaging, antimikroba dari rimpang. Senyawa aktif yang umumnya bertanggungjawab terhadap aktivitas farmakologi adalah golongan fenol, flavonoid, saponin dan minyak atsiri.

\section{DAFTAR PUSTAKA}

Adrian, K. 2017. Ini Fakta Flavonoid yang Perlu Anda Ketahui. Retrieved August 2, 2019, from Alodokter website: https://www.alodokter.com/ini-faktaflavonoid-yang-perlu-anda-ketahui

Alulyant, A. S., Hiles, H., \& Heden, P. 1996. Analisis glc-ms minymc atsiri rimpang Curcuma heyneana. Majalah Farmasi Indonesia, 7(1996). Retrieved from http://i-lib.ugm.ac.id/jurnal/detail.php?dataId=7495

Anonim. 2014. Senyawa Fenolik. Retrieved from http://tip.ub.ac.id/wpcontent/uploads/2016/08/PBA9_Fenol_Flavonoid.pdf

Arifah, H., Permatasari, R. I., \& Fitri, H. E. 2011. Bedak Temugiring. Retrieved August 2, 2019, from http://fmipa.uny.ac.id/berita/bedak-temugiring.html

Backer, \& Van Den Brink, B. 1968. Flora of Java (Spermatophytes Only). Leyden: The Auspices of The Rukserbarium. 
Bos, R., Windono, T., Woerdenbag, H. J., Boersma, Y. L., Koulman, A., \& Kayser, O. 2007. HPLC-photodiode array detection analysis of curcuminoids in Curcuma species indigenous to Indonesia. Phytochemical Analysis, 18(2), 118-122. https://doi.org/10.1002/pca.959.

Dwisatyadini, M. 2017. Pemanfaatan Tanaman Obat Untuk Pencegahan dan Pengobatan Penyakit Degeneratif. Optimalisasi Peran Sains Dan Teknologi Untuk Mewujudkan Smart City, 237-270.

Dzulkarnain, B., Widowati, L., Pudjiastuti, P., Astuti, Y., Chozin, A., \& Nuratmi, B. (Eds.). 1995. Tinjauan Hasil Penelitian Tanaman Obat di Berbagai Institusi II. Jakarta: Pusat Penelitian dan Pengembangan Farmasi Badan Penelitian dan Pengembangan Kesehatan RI.

Hapsari, D. 2015. Sub-Acute Toxicity Test of Curcuma Heyneana Infusion on Ddy (deutschland-Denken-Yoken) Mice: An Evaluation on Histopathological Finding on Liver and Kidney (Universitas Gadjah Mada). Retrieved from http://etd.repository.ugm.ac.id/index.php?mod=penelitian_detail\&sub=Pene $\underline{\text { litianDetail\&act=view \&typ=html\&buku } \_ \text {id }=80093}$

Hendrian, H., \& Hadiah, J. T. (Eds.). 1999. In Koleksi Tumbuhan Obat Kebun Raya Bogor (p. 65). Bogor: UPT Balai Pengembangan Kebun Raya LIPI.

Jane Beers, S. (2001). Jamu (The Ancient Indonesian Art of Herbal Healing) (1st ed.). Singapore: Tuttle Publishing.

Kemendag. 2014. Minyak Atsiri (HS 3301). Berlin: ATASE PERDAGANGAN KBRI BERLIN.

Kusumawati, I., Kurniawan, K.O., Rullyansyah, S., Prijo, T.A., Widyowati, R., Ekowati, J., Hestianah, E.P., Maat, S., Matsunami, K. 2018. Anti-aging properties of Curcuma heyneana Valeton \& Zipj: A scientific approach to its use in Javanese tradition. Journal of Ethnopharmacology, 225, 64-70. https://doi.org/10.1016/j.jep.2018.06.038

Lestari, T., Yunianto, B., \& Winarso, A. 2017. Evaluasi Mutu Salep Dengan Bahan Aktif Temugiring, Kencur Dan Kunyit. JURNAL KEBIDANAN DAN KESEHATAN TRADISIONAL, 2(1). Retrieved from http://jurnal.poltekkessolo.ac.id/index.php/JKK/article/view/301

Lolita, Y. S. 2014. AKTIVITAS ANTIVIRAL JAMU VIRANUR (Piper cubeba, Foeniculum vulgae mill, Curcuma heyneana) 1\% TERHADAP VIRUS Avian Influenza (Universitas Gadjah Mada). Retrieved from http://etd.repository.ugm.ac.id/index.php?mod=penelitian_detail\&sub=Pene $\underline{\text { litianDetail\&act=view \&typ=html\&buku_id=72649 }}$

Maulida, A. N. 2016. UJI EFEKTIVITAS KRIM EKSTRAK TEMU GIRING (Curcuma heyneana Val). 5. 
Mudjijono, M., Herawati, I., Munawaroh, S., \& Sukari, S. 2014. Kearifan Lokal Orang Madura (Jamu untuk Menjaga Kesehatan Ibu dan Anak) (1st ed.). Yogyakarta: Balai Pelestarian Nilai Budaya (BPNB) Yogyakarta.

Muhlisah, F. 1999. Тетu-Temuan dan Empon-emponan Budidaya dan Manfaatnya. Presented at the Yogyakarta. Yogyakarta: Penerbit Kanisius.

Nuraeni, C., \& Yunilawati, R. 2012. Identifikasi Komponen Kimia Minyak Atsiri Temugiring (Curcuma heyneana Val. \& v. Zijp) dan Temukunci (Kaempheria pandurata Roxb.) Hasil Distilasi Air-Uap. Jurnal Kimia dan Kemasan, 34(1), 187-191. https://doi.org/10.24817/jkk.v34i1.1851

Rahmawati, A. A. D. 2019. Lengkuas hingga Temu Giring, Bumbu Dapur Sehat yang Bikin Makanan Enak. Retrieved July 31, 2019, from Detikfood website: https://food.detik.com/info-sehat/d-4385779/lengkuas-hinggatemu-giring-bumbu-dapur-sehat-yang-bikin-makanan-enak

Saifudin, A., Tanaka, K., Kadota, S., \& Tezuka, Y. 2013. Sesquiterpenes from the Rhizomes of Curcuma heyneana. Journal of Natural Products, 76(2), 223229. https://doi.org/10.1021/np300694a

Salim, Z., Munadi, E., Nugroho, R.A., Ningsih, E.A., Paryadi, D., Utama, R., Saputri, A.S., Andrian, N., Faradila, F. 2017. Info Komoditi Tanaman Obat (1st ed.). Jakarta: Badan Pengkajian dan Pengembangan Perdagangan Kementerian Perdagangan Republik Indonesia.

Santoso, H. B. 1998. Toga 2 Tanaman Obat Keluarga (8th ed.). Yogyakarta: Penerbit Kanisius.

Setiowati, E. 2014. Memahami Kriteria Kualitas Penelitian: Aplikasi Pemikiran Penelitian Kualitatif Maupun Kuantitatif. Jurnal Vokasi Indonesia, 2(2), 42-49.

Syamsuhidayat, S. S., \& Hutapea, J. R. 1991. Inventaris Tanaman Obat Indonesia (I). Jakarta: Badan Penelitian dan Pengembangan Kesehatan Departemen Kesehatan RI.

Tukiman, T. 2004. Pemanfaatan Tanaman Obat Keluarga (TOGA) Untuk Kesehatan Keluarga. Medan: USU digital library.

Yanuartono, Y., Purnamaningsih, H., Nururrozi, A., \& Indarjulianto, S. 2017. Saponin: Dampak terhadap Ternak (Ulasan). Jurnal Peternakan Sriwijaya, 6(2). https://doi.org/10.33230/JPS.6.2.2017.5083.

Yustin, L. J., \& Wijayanti, E. D. 2018. Aktivitas Antioksidan Sari Rimpang Temu Giring (Curcuma heyneana) Terfermentasi Lactobacillus bulgaricus. JC-T (Journal Cis-Trans): Jurnal Kimia Dan Terapannya, 2(1). https://doi.org/10.17977/um026v2i12018p001. 